Article

\title{
Depression, Acculturative Stress, and Social Connectedness among International University Students in Japan: A Statistical Investigation
}

\author{
Minh Hoang Nguyen ${ }^{1}$, Tam Tri Le ${ }^{1}$ and Serik Meirmanov ${ }^{2, *}$ \\ 1 International Cooperation Policy, Graduate School of Asia Pacific Studies, Ritsumeikan Asia Pacific \\ University, Beppu, Oita 874-8577, Japan; minhhn17@apu.ac.jp (M.H.N.); tamtle17@apu.ac.jp (T.T.L.) \\ 2 Public Health Management Division, Graduate School of Asia Pacific Studies, Ritsumeikan Asia Pacific \\ University, Beppu, Oita 874-8577, Japan \\ * Correspondence: serikmed@apu.ac.jp
}

Received: 23 December 2018; Accepted: 3 February 2019; Published: 8 February 2019

\begin{abstract}
This study aims to examine the prevalence of depression and its correlation with Acculturative Stress and Social Connectedness among domestic and international students in an international university in Japan. (2) Methods: A Web-based survey was distributed among several classes of students of the university, which yielded 268 responses. On the survey, a nine-item tool from the Patient Health Questionnaire (PHQ-9), the Social Connectedness Scale (SCS) and Acculturative Stress Scale for International Students (ASSIS) were used together with socio-demographic data. (3) Results: The prevalence of depression was higher among international than domestic students ( $37.81 \%$ and $29.85 \%$, respectively). English language proficiency and student age (20 years old) showed a significant correlation with depression among domestic students $(\beta=-1.63, p=0.038$ and $\beta=2.24, p=0.048$ ). Stay length (third year) also displayed a significant correlation with depression among international students $(\beta=1.08, p=0.032)$. Among international and domestic students, a statistically significant positive correlation between depression and acculturative stress, and negative associations of social connectedness with depression and acculturative stress were also found. (4) Conclusions: The high prevalence of depression, and its association with Acculturation stress and Social Connectedness, among the students in this study highlight the importance of implementing support programs which consider the role of Acculturation and Social Connectedness.
\end{abstract}

Keywords: depression; acculturation stress; social connectedness; international students; university students; ASSIS; Mindsponge; multicultural

\section{Introduction}

The rapid spread of globalization has made countries worldwide increasingly interconnected in many aspects, including in education. The number of globally mobile students increased by $25.3 \%$ from 2012 to 2017 [1]. Understanding the mental health condition among international students will help sustain the development of the social public health system, especially in countries with a high number of international students.

Depressive disorder is a major public health concern which affects 322 million people globally. In 2015, global depression prevalence was 4.4\%. Together with HIV/AIDS and heart disease, depression was projected to be one of the three leading causes of burden of disease until 2030 [2]. If becoming too severe, depression can lead to suicide-the second leading cause of death for people aged 15-29 [3].

High depression prevalence $(4.2 \%)$ is a serious problem to the sustainable public health development in Japan [3]. In 2008, depression entailed a substantial burden to the Japanese economy 
by costing approximately $\$ 11$ billion [4]. Depressive disorder was also among the top causes of suicide in Japan $[5,6]$.

Depression is more prevalent in university students compared to the general population [7], even in Japan. Major depressive disorder prevalence among first-year university students in Japan was reported at $20.7 \%, 53.4 \%$, and $23.3 \%$ according to three different measurements [8]. Another paper found that around $30 \%$ of university students in Japan had depressive state [9]. As the number of international students in Japan increased rapidly by $45 \%$ in the last 3 years (from 184,155 in 2014 to 267,042 in 2017) [10], the mental health of international students has become a major concern. The prevalence of depression of international students in Japan was $41 \%$ [11]. A proportion of $34 \%$ of students visiting the mental health service at Tsukuba University health center informed being depressed [12].

Studies of factors contributing to depression in university students vary among countries regarding their findings [13-19]. For instance, a study in Kenya showed significant correlations between higher depression and year of study, academic performance, religion, age [14], while another study in Malaysia indicated significant associations of depression with age, gender, and economic status [15].

There were several studies on the predictors of depressive disorder in Japan. For instance, personality traits, such as self-directedness and harm avoidance, were significantly correlated with major depressive disorder in Japanese university students [20]. Negative automatic thought was found to be positively corelated with depression [21]. University life satisfaction and lifestyle (irregularity of meal and wake-up time) also contributed to depression among Japanese students. Meanwhile, gender, course category, and residential arrangement significantly correlated with depression among international students in Japan [11]. Overall, few studies about predictors of depression among domestic and international students in Japan have been conducted.

The results of cultural and psychological changes from moving to a foreign country or living in a new cultural environment are known as acculturation [22]. As international students start living in a new environment, intercultural contacts can cause acculturative stress, so they need to adapt to harmonize potential conflicts. Findings of many studies showed a significantly positive correlation between acculturative stress and depression [23-26]. Knowing more how acculturative stress is linked to depression in an international university will help improve the support systems for student's mental health. Findings of research about acculturation are mostly about acculturative stress, psychological adjustment, social belonging, depression, and anxiety [27]. While there are plenty of studies about acculturative stress in general immigrants $[23,25,26]$ and international students in the US [28-30], the amount of studies on students in an international university in other country is still limited. University students have a worse quality of life [31]. The mental health condition of international university students needs special attention, especially considering the challenges they need to overcome when living in a new environment.

Social connectedness reflects an individual's opinion of themselves in relation to other people within a social context [32]. When the sense of connectedness of a person declines, that person starts to feel distant and different from other people and recall where it belongs [32]. Social connectedness is a predictor of depression among college students [33] and acculturative stress among international students [34]. International students who leave their home country to study in an entirely new environment become disconnected with their old relationships and connections. These losses might pose threat to student's mental health, such as depression. However, studies regarding the association between social connectedness and depression among students at an international university remain limited.

An international university is where students and faculties from different societies and cultural background are placed together. According to the Times Higher Education, the international outlook of a university is assessed based on three factors: the proportion of international students, the proportion of international staffs, and its international collaboration [35]. As a result, the greater the proportion of 
international students and faculties from various countries and regions is, the more multicultural the international university becomes.

It is worth nothing that studying in an international university is a double-edged experience. On the one hand, individuals being in a multicultural environment might receive many positive outcomes, for example, having a higher degree of cultural additivity [36] and behaving appropriately under multiple cultural contexts [37]. On the other hand, living in a multicultural environment could lead to problems of acculturation, such as feeling being rejected from multiple cultural contexts [38]. Not only international but even domestic students might experience difficulties in adjusting to the environment of international university. This is why it is important to understand the impact of acculturation and an individual's sense of connectedness on depression level in an international university.

To our knowledge, there was no comparative study concerning depression, acculturative stress, and social connectedness among domestic and international students in Japan. Since the literature about depression prevalence and the association of depression with acculturative stress and social connectedness in an international university is still limited, this study aims to examine: (1) the prevalence and predictors of depression and (2) the hypotheses of associations of depression with acculturative stress and social connectedness among domestic and international students at an international university. On the basis of the examined literature, the study seeks to answer the following research questions (RQ1 and RQ2) and hypotheses (H1 and H2) based on data collected from an international university in Japan:

RQ1: What is the prevalence of depression among domestic and international students?

RQ2: What are the socio-demographic predictors of depression among domestic and international students?

H1: Acculturative stress will be significantly positively associated with depression in both domestic and international students. Students in an international university were expected to have higher depression levels due to extensive conflicts during acculturation process.

H2: Social connectedness will be significantly negatively associated with depression in both domestic and international students. A greater sense of connectedness with others will make individual feel more comfortable and confident within a social context, which will prevent depression.

\section{Materials and Methods}

\subsection{Study Site}

In this study, we selected Ritsumeikan Asia Pacific University (APU), which is situated at Beppu City, Oita Prefecture in southern Japan, as our study area because it is Japan's first truly international university and is currently the most diverse university in Japan in terms of international faculty and student [39]. As of 2017, the number of international students and faculties on APU campus consisted of $50.1 \%$ of total 5,887 students and $49.4 \%$ of 166 faculty members, respectively [40]. The diversity of this university is not only limited to the proportion of students and faculties but also their variety of origins. According to official statistics of the university in 2018, international students came from 86 countries and regions, while the faculty members are from 22 different countries and regions [41]. The diversity of APU made an appropriate site for studying students in a multicultural environment-a subject found to be limited within the extant scholarship.

\subsection{Participants}

The study collected web-based questionnaires (Google Forms) of 268 students from a variety of countries who are currently studying at APU. A proportion of $75 \%$ of the number of participants were international students $(\mathrm{N}=201)$, while domestic students accounted for $25 \%(\mathrm{~N}=67)$. Among 201 international students, the highest percentages of students were from South East Asia (75\%), including Vietnam, Indonesia, Thailand, and Malaysia. Students originating from East Asia, which consists of 
China Korea, and Taiwan, accounted for 25\%. Students from South Asia and other areas accounted for $9 \%$ and $5 \%$, respectively.

Participants consisted of 170 females (63.4\%) and 98 males (36.6\%), with half of them being freshmen or who had been staying in APU within one year (see Table 1). As for language proficiency, around $76 \%$ of international students could speak English with high proficiency, whereas most of the native students acquired medium English proficiency and only 20\% of them could use English fluently. The rate of international students able to speak the Japanese language fluently was quite low with only $12.6 \%$, and almost half of them informed acquiring low Japanese proficiency. More than half of the participants, both domestic and international students, reported that they had no intimate partner at the time of filling the questionnaire (seven participants failed to report whether they had an intimate partner). The number of international students reported being religious was higher than that domestic students (37.31\% compared to $23.88 \%$ ).

Table 1. Socio-demographic characteristics of domestic and international students.

\begin{tabular}{|c|c|c|c|c|c|c|}
\hline & \multicolumn{3}{|c|}{ Domestic Students } & \multicolumn{3}{|c|}{ International Students } \\
\hline & $\begin{array}{c}\text { Total } \\
(\mathrm{N}=67) \\
\text { Weighted \% }\end{array}$ & $\begin{array}{c}\text { Male } \\
(\mathrm{N}=25) \\
\text { Weighted \% }\end{array}$ & $\begin{array}{c}\text { Female } \\
(\mathrm{N}=42) \\
\text { Weighted \% }\end{array}$ & $\begin{array}{c}\text { Total } \\
(\mathrm{N}=201) \\
\text { Weighted \% }\end{array}$ & $\begin{array}{c}\text { Male } \\
(\mathrm{N}=73) \\
\text { Weighted \% }\end{array}$ & $\begin{array}{c}\text { Female } \\
(\mathrm{N}=128) \\
\text { Weighted \% }\end{array}$ \\
\hline \multicolumn{7}{|l|}{ Age } \\
\hline $17-19$ & 28.36 & 20.00 & 33.33 & 35.82 & 31.51 & 38.28 \\
\hline 20 & 25.37 & 40.00 & 16.67 & 16.92 & 10.96 & 20.31 \\
\hline$>20$ & 46.27 & 40.00 & 50.00 & 47.26 & 57.53 & 41.41 \\
\hline \multicolumn{7}{|c|}{ Length of stay } \\
\hline Freshman & 29.85 & 24.00 & 33.33 & 47.26 & 45.21 & 48.44 \\
\hline 2 years & 19.40 & 24.00 & 16.67 & 19.40 & 16.44 & 21.09 \\
\hline 3 years & 34.33 & 28.00 & 38.10 & 22.89 & 23.29 & 22.66 \\
\hline$>3$ years & 16.42 & 24.00 & 11.90 & 10.45 & 15.07 & 7.81 \\
\hline \multicolumn{7}{|c|}{ English } \\
\hline \multicolumn{7}{|l|}{ Proficiency } \\
\hline Low & 22.39 & 20.00 & 23.81 & 3.48 & 2.74 & 3.91 \\
\hline Average & 58.21 & 60.00 & 57.14 & 20.40 & 15.07 & 23.44 \\
\hline High & 16.42 & 16.00 & 16.67 & 58.71 & 67.12 & 53.91 \\
\hline Native & 2.99 & 4.00 & 2.38 & 17.41 & 15.07 & 18.75 \\
\hline \multicolumn{7}{|l|}{ Japanese } \\
\hline \multicolumn{7}{|c|}{ Proficiency } \\
\hline Low & 1.49 & 4.00 & - & 45.27 & 41.10 & 47.66 \\
\hline Average & 5.97 & 8.00 & 4.76 & 42.29 & 42.47 & 42.19 \\
\hline High & 1.49 & 4.00 & - & 11.94 & 16.44 & 9.38 \\
\hline Native & 91.04 & 84.00 & 95.24 & 0.50 & - & 0.78 \\
\hline \multicolumn{7}{|c|}{ Intimate partner } \\
\hline Yes & 40.30 & 40.00 & 40.48 & 37.81 & 30.14 & 42.19 \\
\hline No & 59.70 & 60.00 & 59.52 & 58.21 & 60.27 & 57.03 \\
\hline \multicolumn{7}{|l|}{ Religion } \\
\hline Yes & 23.88 & 24.00 & 23.81 & 37.31 & 45.21 & 32.81 \\
\hline No & 76.12 & 76.00 & 76.19 & 62.69 & 54.79 & 67.19 \\
\hline
\end{tabular}

\subsection{Instruments}

\subsubsection{Measures of Depression}

The PHQ-9, a nine-item tool from the Patient Health Questionnaire (PHQ), was used to measure Depression. The questionnaire consists of 9 questions based on the Diagnostic and Statistical Manual for Mental Disorders-4th edition (DSM-IV) criteria for diagnosis depression. With only nine questions, the PHQ-9 can be used for dual purposes, being the diagnosis of depressive disorder and grade depressive symptom severity [42]. By asking the participants about the frequency of various symptoms over the past two weeks, the study then categorized the respondents as having major depressive disorder or other depressive disorder. The respondents are diagnosed positive to major depressive 
disorder or other depressive disorder if 5 or 2 depressive symptoms respectively present at least "more than half of the days" over the past two weeks, and one of the symptoms needs to be depressed mood or anhedonia [43]. Notably, the symptom "thoughts that you would be better off dead or of hurting yourself in some way" is counted regardless of the duration. To estimate the severity of depression, the DSM-IV criteria are scored as "0" (not at all) to " 3 " (nearly every day) in the PHQ-9, and thus the depressive severity score ranges from 0 to 27 . The severity of depression is also categorized into five levels (minimal depression, mild depression, moderate depression, moderately severe depression, and severe depression) based on the score 1-4, 5-9, 10-14, 15-19, and 20-27 accordingly.

The validity of the PHQ-9 was tested for correlation with diagnosis by many mental health studies $[44,45]$. In the original study, Spitzer et al. acquired the validation of sensitivity and specificity at $73 \%$ and $98 \%$, respectively, for significant depression among primary care patients [46]. The PHQ-9 was used to measure depression of not only patients but also a wide range of populations, including international students $[44,45,47,48]$. The Cronbach alpha measured in this study were 0.81 and 0.80 for international and domestic students respectively, which were acceptable.

\subsubsection{Measures of Social Connectedness}

The measure of Social Connectedness in this research was the Social Connectedness Scale (SCS) developed by Lee and Robbins to evaluate an individual's emotional distance or connectedness between themselves and other people [32]. The Social Connectedness Scale consists of 8 items representing three aspects of belongingness: Connectedness (4 items), Affiliation ( 3 items), and Companionship (1 item). Each item is rated on a 6-point Likert scale ranging from 1 (Strongly Disagree) to 6 (Strongly Agree). A sample is "I feel disconnected from the world around me". The total score is the sum of 8 items, with higher scores indicating higher social connectedness. The potential score of Social Connectedness ranges from 6 to 48 .

In the original study of Social Connectedness scale, the internal reliability or coefficient of Cronbach's alpha estimated was 0.91 [32], whereas alpha coefficients in other studies ranged from 0.83 to 0.93 [34,49-52]. The Alpha Coefficient in this study of international and domestic students was similar with 0.95 . The construct validity was also supported by a negative association with anxiety, a positive association with self-esteem [53], and a negative correlation with acculturative stress [34].

\subsubsection{Measures of Acculturative Stress}

This study measured acculturative stress using the Acculturative Stress Scale for International Students (ASSIS) developed by Sandhu and Asrabadi [54]. The ASSIS, a 36-item questionnaire about acculturative stress of international students, covers 7 major factors: Perceived Discrimination (8 items), Homesickness (4 items), Perceived Hatred (5 items), Fear (4 items), Culture Shock ( 3 items), Guilt (2 items), and Miscellaneous (10 items). Each item is scored on a 5-point Likert scale ranging from 1 (strongly disagree) to 5 (strongly agree). The sum of all 7 major factors represents the total score of acculturative stress. The higher the total score, the higher the degree of acculturative stress international students undergo. However, since this study was conducted in an English-speaking campus in a country where English is not the native language, the survey was modified suitably for the study area. Specifically, based on the item "I feel nervous to communicate in English", there was on additional item related to student's Japanese proficiency: "I feel nervous to communicate in Japanese." On the other hand, as the factor related to social connectedness was covered in the SCS, the item "I feel intimidated to participate in social activities" was omitted to keep the total score from 36 to 180.

In other research, the alpha coefficient for acculturative stress total score ranged from 0.92 to 0.95 for international students $[28,29,34,50]$. In this study, the alpha coefficient was 0.95 for both international students and domestic students, indicating a high average inter-item correlation. The construct validity of ASSIS was supported by the positive correlation with depression [28,29] and mental health [55], and the negative correlation with condom-use intentions [55]. 


\subsection{Procedure}

The questionnaire was approved by the Ethical Committee Board of APU. Google Forms was selected as the platform to conduct the questionnaire because it is common and easy to manage. After a brief explanation of the project, the link to the questionnaire was distributed in several classes and among the APU Vietnamese community from the end of 2018. We chose the Vietnamese community as two authors are originally from Vietnam. After the announcement, survey was available online and students had the chance to answer the survey at their convenience (campus, home, library, etc.). The total response rate was $40.05 \%$ (268/669).

Informed consent was obtained from each participant: after following the survey link, each participant read the informed consent text together with an explanation on the research's goals (based on APU regulations), below which the participants had the choice to participate or not by choosing "Agree" or "Not agree." The participants had an option to quit survey by choosing "Not agree" or any time later, just by not submitting the survey. In the case of agreeing to participate, each participant was shown the list of questions to which he/she needs to answer.

\subsection{Statistical Analysis}

The statistical analysis of the research consists of two main parts. The first part is for estimating the prevalence of depression and potential socio-demographic predictor of depression, whereas the second part is to test the association of two predictors (social connectedness and acculturative stress) with the severity of depression.

The correlations between depression and socio-demographic factors, such as, gender, age, length of stay, language proficiency, e.g., were examined to find out potential predictors of depression. People who suffered from major or other depressive disorder were considered as being depressed. Dichotomous logistic regression was used as a statistical analysis tool for testing the potential socio-demographic predictor, because of three main points: (1) predetermined number of variables was comprised in the model making it show each variable's significance more clearly; (2) the model can indicate all odd ratios simultaneously between dependent variable and other categories [56]; and (3) binary logistic regression was widely used in other studies with the same topic [45,57-59]. Thus, the examined model of being depressed as dependent variables was presented as follows:

$$
\begin{aligned}
& \ln \left(\frac{p}{1-p}\right)_{\text {depression }}=\ln (\text { Odd Ratios })_{\text {depression }} \\
& =\alpha+\beta_{1 j} \text { gender }_{1 j}+\beta_{2 j} a_{g e_{2 j}}+\beta_{3 j} \text { stay }_{3 j}+\beta_{4 j} E_{n} g_{4 j}+\beta_{5 j} J_{a p_{5 j}} \\
& +\beta_{6 j} \text { partner }_{6 j}+\beta_{7 j} \text { religion }_{7 j}+e \text {, }
\end{aligned}
$$

with

$p$ : the probability of being depressed

$\alpha$ : intercept

$\beta$ : coefficient which is the logarithm of Odd Ratios

$j$ : categorical factor of independent variables

gender, age, etc.: independent variables

$e$ : error term.

The binary logistic model was applied to both domestic and international students for comparative purpose. However, as no domestic students reported low Japanese proficiency and very few reported average Japanese proficiency, Japanese proficiency variable was omitted when the model was employed on the data set of domestic students.

Pearson Correlation Coefficient (PCC) analysis was first employed to look at the correlation among main variables used in the study for two reasons: (1) PCC indicates the strength of linear relationship of two variables [60]; and (2) PCC was widely used in studies in the same field [61-64]. According to the Cauchy-Schwartz inequality, PCC ( $r$ ) has a value of between -1 and +1 , where +1 
indicates total positive linear correlation, 0 indicates no linear correlation, and -1 shows total negative linear correlation [65]. Next, to test the two hypotheses $\mathrm{H} 1$ and $\mathrm{H} 2$, multiple regression analysis was conducted to explore the contribution of main variables on predicting depression severity. Multiple regression analysis has been widely used in many other studies of the same field $[23,25,66]$.

Raw data were cleaned in MS Excel and saved as CSV files. The data were then transferred into the database of STATA statistical software (version 15.1) to run statistical analysis. STATA statistical software was used for running dichotomous logistic regression, Pearson Correlation Coefficient, and multiple regression analysis. Additionally, robust statistics was also comprised in the dichotomous logistic regression model to omit outliners [67]. The $p$-value indicated the significance of independent variables in the models. It is conventional to choose $p$-value $<0.05$ as a required statistical significance [68].

\section{Results}

\subsection{Descriptive Results}

According to the PHQ-9, 37.81\% of international students and $29.85 \%$ of domestic students were found to be positive with depression (see Table 2). The proportion of depressed international students was higher than that of domestic students by almost $8 \%$. While international students possessed a lower rate of major depressive disorder (14.93\%) than other depressive disorder $(22.89 \%)$, major depressive disorder (17.91\%) was more significant than other depressive disorder (11.94\%) among domestic students. Among the depressed domestic students, there was not much difference between males and females. On the other hand, international female students $(39.84 \%)$ had a higher rate of depression than male international students (34.25\%).

Table 2. Prevalence of depression.

\begin{tabular}{|c|c|c|c|c|c|c|}
\hline & \multicolumn{3}{|c|}{ Domestic Students } & \multicolumn{3}{|c|}{ International Students } \\
\hline & $\begin{array}{c}\text { Total } \\
(\mathrm{N}=67) \\
\text { Weighted \% }\end{array}$ & $\begin{array}{c}\text { Male } \\
(\mathrm{N}=25) \\
\text { Weighted \% }\end{array}$ & $\begin{array}{c}\text { Female } \\
(\mathrm{N}=42) \\
\text { Weighted \% }\end{array}$ & $\begin{array}{c}\text { Total } \\
(\mathrm{N}=201) \\
\text { Weighted \% }\end{array}$ & $\begin{array}{c}\text { Male } \\
(\mathrm{N}=73) \\
\text { Weighted \% }\end{array}$ & $\begin{array}{c}\text { Female } \\
(\mathrm{N}=128) \\
\text { Weighted \% }\end{array}$ \\
\hline Type of depression & 29.85 & 28.00 & 30.95 & 37.81 & 34.25 & 39.84 \\
\hline Other depression & 11.94 & 8.00 & 14.29 & 22.89 & 19.18 & 25.00 \\
\hline Major depression & 17.91 & 20.00 & 16.67 & 14.93 & 15.07 & 14.84 \\
\hline Mild depression & 38.81 & 32.00 & 42.86 & 40.30 & 36.99 & 42.19 \\
\hline Moderate depression & 29.85 & 32.00 & 28.57 & 26.37 & 20.55 & 29.69 \\
\hline Moderately severe depression & 5.97 & 8.00 & 4.76 & 5.47 & 4.11 & 6.25 \\
\hline Severe depression & 4.48 & 4.00 & 4.76 & 2.49 & 4.11 & 1.56 \\
\hline
\end{tabular}

Among international students, the percentage of students being depressed varied according to their regions of origin. International students who were originally from South East Asia had the highest percentage of depression (39.34\%), while students from South Asia possessed the lowest rate of depression (27.78\%), which was even lower than domestic students $(29.85 \%)$. Students from other regions had relatively similar rates of depression at $38 \%$. Similar to domestic students, students from South Asia suffered from major depression (16.67\%) more than other depression (11.11\%).

Of the 67 domestic students and 201 international students, more than half of them only reported minimal depression or mild depression. More domestic students (40.3\%) indicated suffering moderate depression or higher, compared to international students (34.33\%). A higher percentage of moderate and more severe depression was reported in domestic male students (44\%) than in domestic female students (38.09\%). On the contrary, the number of international female students (37.5\%) undergoing moderate to severe depression exceeded the number of international male students $(28.77 \%)$

Based on the PHQ-9, ASSIS, and SCS, the average total scores of each concept was presented in Figure 1. As can be seen, domestic students (8.61) had higher average stress level compared to that of 
international students (8.04), but the difference was negligible. Domestic and international students shared a relatively same level of social connectedness. The result also indicated that acculturative stress was perceived more strongly among international students (75.56) than domestic students (62.88).

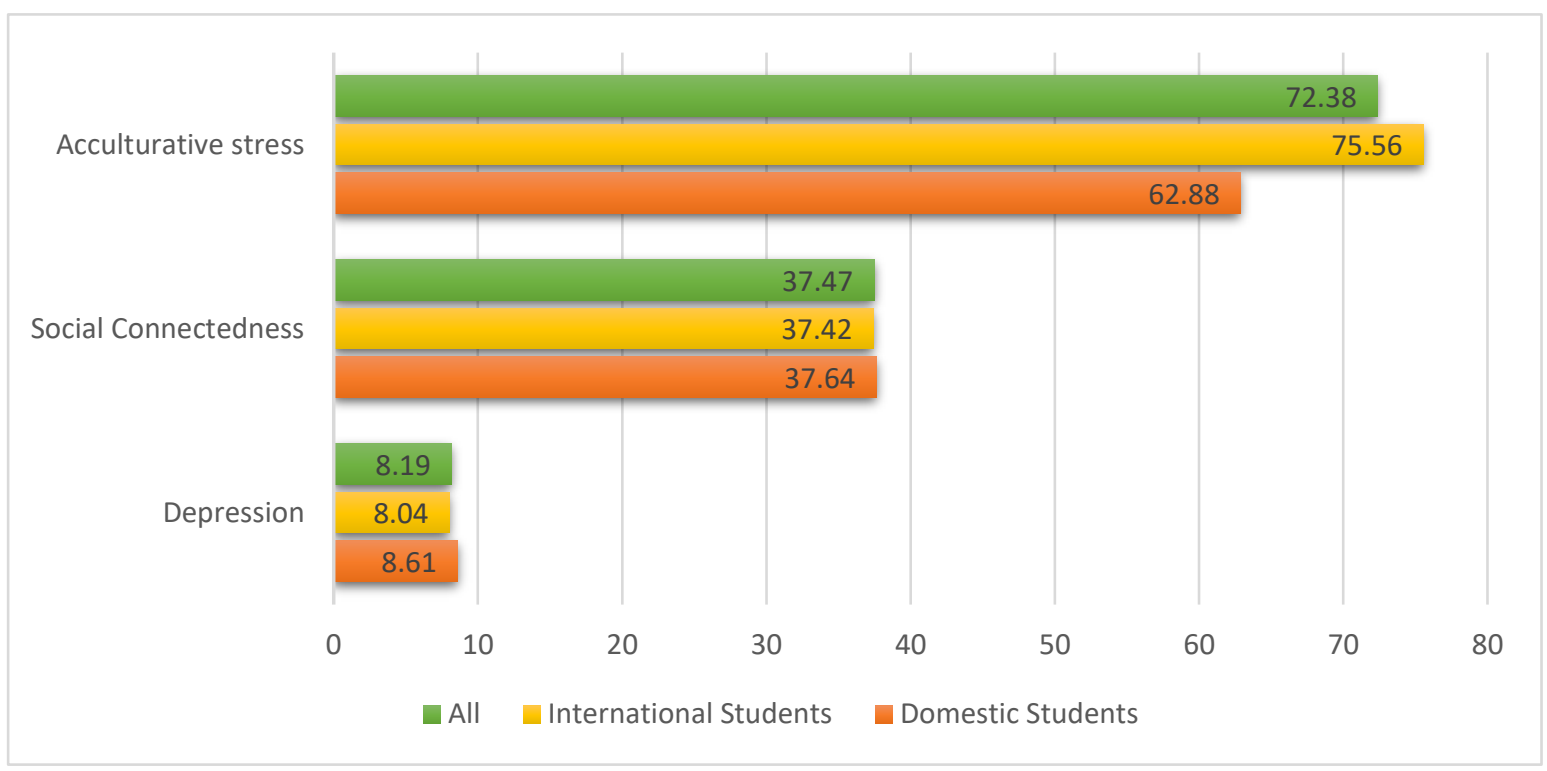

Figure 1. The total scores for depression, social connectedness, and acculturative stress among international and domestic students.

\subsection{Main Analysis}

\subsubsection{Binary Logistic Regression Analysis}

The results of the dichotomous logistic regression with the dependent variable "depression" on the independent socio-demographic variables were displayed in Table 3. In Table 3, there are also the estimated coefficients and the $p$-value of each variable for both domestic students and international students (with the coefficient being the logarithm of Odd Ratio).

The results showed multiple socio-demographic characteristics predicting the depression in domestic students at $p$-value $<0.05$, whereas only one potential predictor can be found in international students. Domestic students in the age of 20 were more likely to have depression than those with ages from 17 to 19 ( $\beta=2.24, p=0.048)$. Another predictor of depression among domestic students was English proficiency. Domestic students speaking average English had a lower rate of being depressed than those who acquired low English proficiency $(\beta=-1.63, p=0.038)$. On the other hand, the only predictor for international students was the length of stay. International students living in Japan for three years suffered from a higher risk of being depressed than first-year students ( $\beta=1.08, p=0.032)$. 
Table 3. Coefficient $(\beta)$ and $p$-value for predictors of depression.

\begin{tabular}{|c|c|c|c|c|}
\hline & \multicolumn{2}{|c|}{ Domestic Students } & \multicolumn{2}{|c|}{ International Students } \\
\hline & $\beta$ & $p$-Value & $\beta$ & $p$-Value \\
\hline \multicolumn{5}{|c|}{ Gender: Male } \\
\hline Female & 0.24 & 0.721 & 0.05 & 0.879 \\
\hline \multicolumn{5}{|l|}{ Age: 17-19 } \\
\hline 20 & 2.24 & $0.048 *$ & -0.87 & 0.129 \\
\hline$>20$ & 2.24 & 0.104 & -0.59 & 0.216 \\
\hline \multicolumn{5}{|c|}{ Length of stay: Freshman } \\
\hline 2 years & -1.46 & 0.190 & 0.80 & 0.103 \\
\hline 3 years & -2.63 & 0.063 & 1.08 & $0.032 *$ \\
\hline$>3$ years & -2.87 & 0.096 & 1.04 & 0.106 \\
\hline \multicolumn{5}{|c|}{ English Proficiency: Low } \\
\hline Average & -1.63 & $0.038 *$ & -0.03 & 0.968 \\
\hline High & -1.33 & 0.112 & -0.27 & 0.720 \\
\hline Native & - & - & 0.40 & 0.621 \\
\hline \multicolumn{5}{|c|}{ Japanese Proficiency: Low } \\
\hline Average & - & - & -0.04 & 0.910 \\
\hline High & - & - & -0.25 & 0.638 \\
\hline Native & - & - & - & - \\
\hline \multicolumn{5}{|c|}{ Intimate partner: No } \\
\hline Yes & 0.42 & 0.549 & 0.20 & 0.55 \\
\hline \multicolumn{5}{|c|}{ Religion: No } \\
\hline Yes & -0.91 & 0.255 & -0.45 & 0.180 \\
\hline
\end{tabular}

Note: ${ }^{*}$ and ${ }^{* * *}$ are statistically significant at 0.05 and 0.001 , respectively.

\subsubsection{Pearson Coefficient Correlation Analysis}

In pairwise correlation analysis (see Tables 4 and 5), all relationships were found to be statistically significant at $p$-value $<0.001$ for both international and domestic students. According to the finding, our hypotheses were confirmed that social connectedness significantly negatively correlated with depression in both domestic and international students $(\mathrm{r}=-0.6$ and $\mathrm{r}=-0.54$, respectively), and that acculturative stress significantly positively corresponded with depression in international students $(\mathrm{r}=0.41)$. In other words, students with high social connectedness would be more likely to have higher depression levels, while international students with higher acculturative stress levels reported higher depression levels.

Table 4. Correlational relationship among Depression, Acculturative Stress, and Social Connectedness (Domestic students).

\begin{tabular}{|c|c|c|c|}
\hline Pearson Correlation (Domestic Student) & 1 & 2 & 3 \\
\hline 1. Depression & 1.00 & & \\
\hline 2. Acculturative stress & $0.45^{* * *}$ & 1.00 & \\
\hline 3. Social Connectedness & $-0.60^{* * *}$ & $-0.55^{* * *}$ & 1.00 \\
\hline
\end{tabular}

Table 5. Correlational relationship among Depression, Acculturative Stress, and Social Connectedness (International students).

\begin{tabular}{cccc}
\hline Pearson Correlation (International Student) & $\mathbf{1}$ & $\mathbf{2}$ & $\mathbf{3}$ \\
\hline 1. Depression & 1.00 & & \\
2. Acculturative stress & $0.41^{* * *}$ & 1.00 & \\
3. Social Connectedness & $-0.54^{* * *}$ & $-0.58^{* * *}$ & 1.00 \\
\hline Note: ${ }^{*}$ and ${ }^{* * *}$ are statistically significant at 0.05 and 0.001 , respectively. &
\end{tabular}


The finding also indicated a significantly negative relationship between social connectedness and acculturative stress in international students $(\mathrm{r}=-0.58)$. International students suffering from high acculturative stress reported lower sense of connectedness with surroundings. Additionally, there were statistically significant correlations of acculturative stress with depression and social connectedness estimated among domestic students $(r=0.45$ and $r=-0.55$, respectively). The decrease of acculturative stress corresponded with the decrease of depression among domestic students, whereas the growing feeling of being connected to others correlated with less stress occurring during acculturation.

\subsubsection{Multiple Regression Analysis}

The normality of the dependent variable was first evaluated using the Skewness and Kurtosis normality test to make sure the variable was normally distributed. The Skewness and Kurtosis of international students were 0 and 0.06 , respectively, indicating a normal distribution. On the other hand, those of domestic students were 0.14 and 0.41 , indicating a mild nonnormality [28]. Therefore, we used square-root transformation for the dependent variable of domestic student [69]. After transformation, the Skewness and Kurtosis of domestic students were 0 and 0.15 , indicating a normal distribution similar to those of international students. The transformed dependent variable of domestic students was used in the remaining of the analysis.

Domestic students. Regressing two main variables on transformed depression, results showed that the model accounted for $35.7 \%\left(R^{2}=0.357\right)$ of the variance (see Table 6$)$. The $F$ value of the model, $F(2,64)=17.77$ was statistically significant at $p$-value $<0.001$. Both of the main predictors had statistically significant association with depression. Social connectedness was negatively correlated with depression $(\beta=-0.044, p$-value $<0.01)$. This indicated that people with stronger feeling of connectedness were likely to have lower severity of depression. Meanwhile, acculturative stress had a positively significant relationship with level of depression $(\beta=0.014, p$-value $<0.05)$. In other words, domestic students with higher acculturative stress would likely suffer from more severe depression.

Table 6. Multiple regression analyses.

\begin{tabular}{ccccc}
\hline & \multicolumn{2}{c}{ Domestic Students } & \multicolumn{2}{c}{ International Students } \\
\cline { 2 - 5 } & $\beta$ & $p$-Value & $\beta$ & $p$-Value \\
\hline Social connectedness & -0.044 & $0.001^{* *}$ & -0.241 & $0.000^{* * *}$ \\
Acculturative stress & 0.014 & $0.026^{*}$ & 0.033 & $0.037^{*}$ \\
\hline $\mathrm{R}^{2}$ & \multicolumn{2}{c}{0.357} & \multicolumn{2}{c}{0.303} \\
$\mathrm{~F}(\mathrm{df})$ & $\mathrm{F}(2,64)=17.77^{* * *}$ & \multicolumn{2}{c}{$\mathrm{F}(2,198)=43.15^{* * *}$} \\
\hline
\end{tabular}

Note: ${ }^{*}$ and ${ }^{* * *}$ are statistically significant at 0.05 and 0.001 , respectively.

International students. The regression analysis of the international student sample showed similar results to the domestic student sample. The goodness of fit of the international sample $\left(R^{2}=0.303\right)$ was smaller than that of domestic samples, while the $\mathrm{F}$ value was still significant at $p$-value $<0.001$ with $\mathrm{F}(2,198)=43.15$. All two main variables significantly predicted depression level. International students feeling connected to surrounding people were more likely to have low depression level ( $\beta=0.033, p$-value $<0.001)$. Higher acculturative stress could also predict more serious depression in international students $(\beta=0.033$, $p$-value $<0.05)$.

The results from both domestic and international students implied the impact of social connectedness and acculturative stress on depression. According to the correlational results from the PCC test, social connectedness and acculturative stress were negatively correlated, social connectedness and acculturative stress might have not only direct impacts but also indirect impacts on the level of depression. Social connectedness could possibly directly affect depression levels and indirectly increase depression levels through escalating acculturative stress, and vice versa for acculturative stress. 


\section{Discussion and Conclusions}

By collecting questionnaires from both domestic and international students at APU, the current study presents a primary investigation on depression, social connectedness, and acculturative stress in a multicultural environment. In the cross-sectional questionnaire of 67 domestic students and 201 international students, the study found that $29.85 \%$ of domestic students and $37.81 \%$ of international students were positive to major depressive disorder or other depressive disorder. In addition, the findings also highlight several socio-demographic predictors (age, English proficiency, and length of stay) and main associations (social connectedness and acculturative stress) of depression. The Mindsponge concept [70] was used to explain the findings.

\subsection{Prevalence of Depression}

According to this study, $30 \%$ of domestic students at APU had depression. This figure is quite common among studies of depression prevalence of students in Japan. In a study using The Center for Epidemiologic Studies Depression Scale (CES-D), one third of the total 105 students reported having mild depression and higher [9]. Based on The Zung Self-Rating Depression Scale (SDS), a study in 2011 also showed $30 \%$ of 2197 of Japanese dental college students having symptoms of moderate or severe depression [71]. As can be seen, the depression rate of Japanese college students was around $30 \%$, which was close to the prevalence of depression among university students (30.6\%) reported in a systematic review of 11 countries [7].

The depression prevalence of international students in this study was $37.81 \%$, while $34 \%$ of international students who visited a mental health service at Tsukuba University health care were found to be depressed [12]. Another study employing the Center for Epidemiologic Studies Depression Scales reported $41 \%$ of 480 international respondents to be depressed [11]. In all cases, the situations of international students were more serious than those of domestic students, which required policy makers, schools, or anyone in charge to pay more attention to the mental health of international students.

The fact that more international students suffer from depression than domestic students can be the consequence of multiple sources. First, international students at an international university received higher level of acculturative stress (see Figure 1), which elevated the risk of being depressed [28-30,55]. Second, international students have lower access to mental health support than domestic students [44,72]. Third, international students have fewer choices of help-seeking sources than their domestic counterparts. For example, it is difficult for international students to seek help from parents and relatives due to the geographical distance [73].

Compared to the depression of students in other countries, the depression prevalence at APU and in Japan, in general, was not high. For example, a study in India employing the University Student Depression Inventory (USDI) showed 53.2\% of students being positive to depression [13]. Using Depression Anxiety Stress Scale-21 (DASS-21), 60.8\% of Egyptian students, 37.2\% of Malaysian students, and 33\% American students reported being depressed $[15,19,74]$. A web-based questionnaire among 4330 students using BAPI depression scale showed that $28.25 \%$ of Turkish students exhibited symptoms of depression [17].

Different levels of prevalence among countries are attributable to several reasons. Different types of questionnaire were used to measure depression (PHQ-9, The Center for Epidemiologic Studies Depression Scale (CES-D) [9], The Zung Self-Rating Depression Scale (SDS) [71], the University Student Depression Inventory (USDI) [13], Depression Anxiety Stress Scale-21 (DASS-21) [15,19,74], and BAPI depression scale [17]). Moreover, the difference might also result from macro-scale, micro-scale, and personal-scale factors. Among the macro-scale factors, depression can be influenced by a socio-economic background in which the university is located, such as income inequality and cultures [75], while the micro-scale factors, which include the living arrangement on campus and academic environment, might play an essential role in driving depression [13]. Apart from that, personal activities, beliefs, and issues might also be crucial contributors to depression $[13,75]$. 
Different levels of prevalence by gender were also noted. In both international and domestic students, a higher proportion of female students was found to be depressed than that of male. This difference might be explained by the fact that female students seem to have higher emotional, physiological, and behavioral reactions to stressors [76].

\subsection{Socio-Demographic Factors Associated with Depression}

In this study, socio-demographic data such as age, gender, length of stay in a new environment, and language proficiency, e.g., were selected to examine the association with depression using dichotomous logistic regression. Compared to another finding of the depression among international students [11], the results here confirmed that age and Japanese language proficiency were not potential predictors of depression among international students in Japan. On the other hand, studies of international students in the United States [77] revealed English proficiency as a predictor for depression. Along this note, the current study did confirm English proficiency as a predictor of depression among the Japanese students. A high percentage of foreign staffs and students, and mandatory English-based subjects for domestic students might be the answers.

Apart from English proficiency, the results also showed two other statistically significant predictors for depression among domestic students. First, age was a significant predictor for depression. Domestic students aged 20 reported having higher rate of being depressed than students with ages between 17 and 19. This finding was consistent with the findings in Kenya and Malaysia [14,15], while the fact that depression did not vary according to age was pointed out in another study in the U.S. [78]. Thus, it might depend on the cultural and social context of the study site to say whether age can be a predictor. In this case, Japanese teenagers were afraid of becoming adults [79], and when Japanese teenagers become 20, they will be considered as adults after the Coming of Age Day (Seijin no Hi). As a result, depression might be more likely to occur among 20-year-old Japanese students.

Another notable result in this study was that third-year international students had a higher chance of being depressed than first-year students. There are several possible explanations: (1) third-year students at APU need to take major courses which are more difficult than the introductory and basic courses in the first and second years; (2) the end of the third year is the period that students have to think about their career paths, and career indecision was positively correlated with depression [80,81].

Findings that age and length of stay were contributors to depression provided some insights of emerging adulthood theory [82] in an Asian country, a topic that has not been explored much. Some people in their late teens to their mid-to late 20s experience serious mental health problem as they do not want to take adult responsibilities and obligations [82,83]. Additionally, facing difficulties and lacking educational information when entering into the labor market might be very stressful for emerging adult students $[84,85]$. In general, depression related to the fear of being an adult or career indecision during the emerging adulthood period does not happen only in Western countries, but also in the Asian settings.

\subsection{Mindsponge Theory as an Explaination for Depression, Social Connectedness and Acculturation}

Findings of the current study confirmed the two main hypotheses that (H1) acculturative stress was significantly positively associated with depression, and (H2) social connectedness was significantly negatively correlated with depression among both domestic and international students. The Mindsponge concept [70] could serve as an explanation for the underlying mechanism among depression, social connectedness, and acculturation among students from a multicultural aspect.

Mindsponge is a concept designed to illustrate the mechanism of how a person absorbs and integrates new cultural values into a his/her own mindset and the reverse of ejecting inappropriate core values (see Figure 1 in the work of Vuong \& Napier [70]).

Acculturative stress. This study found a positive correlation between acculturative stress and depression among domestic and international students. This judgement was supported by similar findings from other studies [23-26,28,29]. Acculturative stress happens during the acculturation 
process as a result of an individual facing various unfamiliar aspects in his/her daily life while trying to adapt to the new environment. Here, students studying in a new environment are prone to acculturative stress, especially those living in a multicultural environment (e.g., climate, food, language, race, landscape, culture) [86].

Living in different environments means facing different cultural and ideological values. Studying in a multicultural environment, students are more likely to be exposed to many new cultural values, which requires adjustment and adaptation. However, it is not easy to for the mindset to integrate and absorb new values. From the external environment to the core value, new cultural values need to get through points of filter. During the filtering process, old and new values are evaluated, connected, and compared [87] to integrate, synthesize, and incorporate values that are compatible or eject waning values. The filtering process is also where the acculturative conflict takes place and causes acculturative stress [22].

The extent to which an individual trusts a new value to be compatible with his/her mindset is the key in the filtering process. Living among new cultural values that an individual has not yet trusted will lead to sustained stress, which may cause brain dysfunction (certain types of depression) [88]. As the conflict becomes more serious, similar to the natural resistance of a human body, the filtering membrane of an individual might receive signal from the mindset to grow thicker to protect the old core values. This, in turn, makes the core values become even more distant with the external values, which greatly raises the level of distrust, intensifies the stress level, and eventually escalates the depression level. For example, low language proficiency makes an individual unable to communicate. Without communication, new cultural values cannot be interpreted, which may lead to distrust of new values, conflict and stress. Eventually, that may give rise to depression.

Social connectedness. The negative association between social connectedness and depression was found in the current study. In other words, social connectedness may help lessen the negative impacts of depression in a multicultural context. The social connectedness reflects "one's opinion of self in relation to other people" in term of emotional distance [32]. When students start to live in a new environment, their social networks begin to change. Living in a new environment where the ideological setting and surrounding people are different, students have to adapt and make new friends. This process can also be explained by the Mindsponge concept.

Assuming the self of an individual is also his/her own mindset. Making new friends is equivalent to accepting new values, so it requires a point of filter. At that point, a friend's personality, perception, and opinion will need to get through a filtering process to make sure whether a self/mindset trusts its new friend/value. If a new friend/value is trustworthy, it can possibly come closer to the self/mindset. This is when a student has a high sense of connectedness. On the other hand, if a new friend/value is in conflicts with the self/mindset, it will be considered as untrustworthy. Functionally, the filter will become thicker, increase the emotional distance from self/mindset to a new friend/value. In other words, feeling difficult to have new friends, students may have no sense of connectedness which may result in strong feeling of hopelessness [89,90] and gradually contribute to loneliness [91]. As loneliness is among the top predictors of depression [91-94] and hopelessness is also positively correlated with depression [95], the lower social connectedness, the higher depression will be. This way of explanation may also be compatible with the association between social connectedness and depression in other population.

In addition, social connectedness under a multicultural context may also have a buffering effect on acculturative stress [34]. As discussed, the mindset increasingly distrusts new value, the distance between mindset and new cultural value is widened due to the rising acculturative conflicts. Social connectedness may contribute to enhance trust of mindset toward new cultural values, which may facilitate the acculturation process. Eventually, since acculturation happens more smoothly, acculturative stress decreases, depression is less likely to happen. 


\section{Recommendations for School Policy}

Based on the above findings, the study suggested some recommendations to have a healthier and more sustainable educational environment in international universities.

- Having a warmer, more close-knit, and friendly education atmosphere is good to enhance trust among students, staffs, and university. By doing so, students will feel more connected to new environment and suffer less from acculturative stress.

- Empowering community-based activities is a potential bottom-up approach for increasing social connectedness, as well as reducing difficulties from acculturation.

- Depression during the emerging adulthood period might be indispensable [82]. Thus, providing appropriate mental and physical supports is necessary. Consultancy or seminar integrating scientific findings [96-98] on the matter of emerging adulthood could be added.

\section{Limitation and Recommendation for Further Research}

This paper has some limitations. In the data collection process, the team used sampling and needed to modify the model questionnaire slightly. In addition, findings were based on self-reported measures.

Regarding of the results on depression, the comparison with the prevalence in other studies might not be precise due to different types of questionnaire used in each study. The questionnaire was collected between November and January, when winter signs were apparent, so depression might be affected by seasonality, primarily when a large number of students originated from tropical areas. The impacts of seasonality on depression were confirmed in other studies [99,100]. Besides that, the current study had higher proportion of females than males, while depression among female students was more prevalent than among male students. The gender disparity in sampling might, therefore, leads to a higher percentage of depression.

The imbalances between the numbers of international and domestic students might be a limitation of this study. Besides that, different proportions of students from different origins might cause the results to have a regional bias among the surveyed international students.

There is a need to find out cause-effect relationships among the correlation, as well as for qualitative studies to provide more in-depth information. The study also recommend a meta-analysis for the mental health of international students in Japan like the following work [101]. This will increase the integration and synthesis of mental health research in Japan. Moreover, the Mindsponge concept was recommended to explain results in mental health study.

Author Contributions: Conceptualization, M.H.N., T.T.L. and S.M.; methodology, M.H.N. and S.M.; software, M.H.N.; validation, M.H.N. and S.M.; formal analysis, M.H.N.; investigation, M.H.N and T.T.L.; resources, M.H.N., T.T.L., and S.M.; data curation, M.H.N.; writing—original draft preparation, M.H.N. and T.T.L.; writing一review and editing, M.H.N. and S.M.; visualization, M.H.N.; supervision, S.M.; project administration, M.H.N. and S.M.; funding acquisition, S.M.

Funding: This research received no external funding.

Acknowledgments: We thank Ho Manh Tung (Ritsumeikan Asia Pacific University) and Nguyen To Hong Kong (Vuong \& Associates) for giving advices and comments that greatly help us during the course of this research. We would also like to show our gratitude to the Research Office of Ritsumeikan Asia Pacific University for facilitating our research process.

Conflicts of Interest: The authors declare no conflict of interest.

\section{References}

1. UNESCO. Education: Outbound Internationally Mobile Students by Host Region. 2019. Available online: http:/ / data.uis.unesco.org/Index.aspx?queryid=172\# (accessed on 26 January 2019).

2. Mathers, C.D.; Loncar, D. Projections of Global Mortality and Burden of Disease from 2002 to 2030. PLoS Med. 2006, 3, e442. [CrossRef] [PubMed] 
3. Depression and Other Common Mental Disorders: Global Health Estimates; World Health Organization: Geneva, Switzerland, 2017.

4. Okumura, Y.; Higuchi, T. Cost of Depression among Adults in Japan. Prim. Care Companion CNS Disord. 2011, 13. [CrossRef]

5. Rupert, W. Hayes Why Does Japan Have Such a High Suicide Rate? BBC News, 2015. Available online: https: / / www.bbc.com/news/world-33362387(accessed on 29 January 2019).

6. The Free Library Suicides Due to Hardships in Life, Job Loss up Sharply in 2009. 17 May 2010. Available online: https:/ / www.thefreelibrary.com/Suicidesduetohardshipsinlife,joblossupsharplyin2009. -a0226580269 (accessed on 29 January 2019).

7. Ibrahim, A.K.; Kelly, S.J.; Adams, C.E.; Glazebrook, C. A systematic review of studies of depression prevalence in university students. J. Psychiatr. Res. 2013, 47, 391-400. [CrossRef] [PubMed]

8. Tomoda, A.; Mori, K.; Kimura, M.; Takahashi, T.; Kitamura, T. One-year prevalence and incidence of depression among first-year university students in Japan: A preliminary study. Psychiatry Clin. Neurosci. 2000, 54, 583-588. [CrossRef] [PubMed]

9. Kawada, T.; Katsumata, M.; Suzuki, H.; Shimizu, T. Actigraphic predictors of the depressive state in students with no psychiatric disorders. J. Affect. Disord. 2007, 98, 117-120. [CrossRef] [PubMed]

10. International Students in Japan; Japan Student Services Organization: Tokyo, Japan, 2017.

11. Eskanadrieh, S.; Liu, Y.; Yamashina, H.; Kono, K.; Arai, A.; Lee, R.; Tamshiro, H. Depressive symptoms among international university students in northern Japan: Prevalence and associated factors. J. Int. Health 2012, 27, 165-170.

12. Takafumi, H.; Terumi, I.; Hirokazu, T.; Naoko, S.; Tadashi, T.; Takashi, A.; Adm Jon, L. An analysis of mental disorders of international students visiting the Mental Health Service at Tsukuba University Health Center. Seishin shinkeigaku zasshi = Psychiatria et neurologia Japonica 2012, 114, 3-12.

13. Deb, S.; Banu, P.R.; Thomas, S.; Vardhan, R.V.; Rao, P.T.; Khawaja, N. Depression among Indian university students and its association with perceived university academic environment, living arrangements and personal issues. Asian J. Psychiatry 2016, 23, 108-117. [CrossRef] [PubMed]

14. Othieno, C.J.; Okoth, R.O.; Peltzer, K.; Pengpid, S.; Malla, L.O. Depression among university students in Kenya: Prevalence and sociodemographic correlates. J. Affect. Disord. 2014, 165, 120-125. [CrossRef] [PubMed]

15. Shamsuddin, K.; Fadzil, F.; Ismail, W.S.W.; Shah, S.A.; Omar, K.; Muhammad, N.A.; Jaffar, A.; Ismail, A.; Mahadevan, R. Correlates of depression, anxiety and stress among Malaysian university students. Asian J. Psychiatry 2013, 6, 318-323. [CrossRef]

16. Sarokhani, D.; Delpisheh, A.; Veisani, Y.; Sarokhani, M.T.; Manesh, R.E.; Sayehmiri, K. Prevalence of Depression among University Students: A Systematic Review and Meta-Analysis Study. Depression Res. Treat. 2013, 2013, 1-7. [CrossRef] [PubMed]

17. Gulec Oyekcin, D.; Sahin, E.M.; Aldemir, E. Mental health, suicidality and hopelessness among university students in Turkey. Asian J. Psychiatry 2017, 29, 185-189. [CrossRef] [PubMed]

18. Jasso-Medrano, J.L.; López-Rosales, F. Measuring the relationship between social media use and addictive behavior and depression and suicide ideation among university students. Comput. Hum. Behav. 2018, 87, 183-191. [CrossRef]

19. Abdel Wahed, W.Y.; Hassan, S.K. Prevalence and associated factors of stress, anxiety and depression among medical Fayoum University students. Alex. J. Med. 2017, 53, 77-84. [CrossRef]

20. Mitsui, N.; Asakura, S.; Takanobu, K.; Watanabe, S.; Toyoshima, K.; Kako, Y.; Ito, Y.M.; Kusumi, I. Prediction of major depressive episodes and suicide-related ideation over a 3-year interval among Japanese undergraduates. PLoS ONE 2018, 13, e0201047. [CrossRef] [PubMed]

21. Tanaka, N.; Uji, M.; Hiramura, H.; Chen, Z.; Shikai, N.; Kitamura, T. Cognitive patterns and depression: Study of a Japanese university student population. Psychiatry Clin. Neurosci. 2006, 60, 358-364. [CrossRef] [PubMed]

22. Berry, J.W. Acculturation: Living successfully in two cultures. Int. J. Intercult. Relat. 2005, 29, 697-712. [CrossRef]

23. Hovey, J.D. Acculturative stress, depression, and suicidal ideation in Mexican immigrants. Cult. Divers. Ethn. Minor. Psychol. 2000, 6, 134-151. [CrossRef] 
24. Tummala-Narra, P.; Alegria, M.; Chen, C.-N. Perceived discrimination, acculturative stress, and depression among South Asians: Mixed findings. Asian Am. J. Psychol. 2012, 3, 3-16. [CrossRef]

25. Revollo, H.-W.; Qureshi, A.; Collazos, F.; Valero, S.; Casas, M. Acculturative stress as a risk factor of depression and anxiety in the Latin American immigrant population. Int. Rev. Psychiatry 2011, 23, 84-92. [CrossRef]

26. Park, H.-S.; Rubin, A. The mediating role of acculturative stress in the relationship between acculturation level and depression among Korean immigrants in the U.S. Int. J. Intercult. Relat. 2012, 36, 611-623. [CrossRef]

27. Brunsting, N.C.; Zachry, C.; Takeuchi, R. Predictors of undergraduate international student psychosocial adjustment to US universities: A systematic review from 2009-2018. Int. J. Intercult. Relat. 2018, 66, 22-33. [CrossRef]

28. Wei, M.; Heppner, P.P.; Mallen, M.J.; Ku, T.-Y.; Liao, K.Y.-H.; Wu, T.-F. Acculturative stress, perfectionism, years in the United States, and depression among Chinese international students. J. Couns. Psychol. 2007, 54, 385-394. [CrossRef]

29. Constantine, M.G.; Okazaki, S.; Utsey, S.O. Self-Concealment, Social Self-Efficacy, Acculturative Stress, and Depression in African, Asian, and Latin American International College Students. Am. J. Orthopsychiatr. 2004, 74, 230-241. [CrossRef] [PubMed]

30. Lee, J.-S.; Koeske, G.F.; Sales, E. Social support buffering of acculturative stress: A study of mental health symptoms among Korean international students. Int. J. Intercult. Relat. 2004, 28, 399-414. [CrossRef]

31. Ribeiro, Í.J.S.; Pereira, R.; Freire, I.V.; de Oliveira, B.G.; Casotti, C.A.; Boery, E.N. Stress and Quality of Life Among University Students: A Systematic Literature Review. Health Prof. Educ. 2018, 4, 70-77. [CrossRef]

32. Lee, R.M.; Robbins, S.B. Measuring belongingness: The Social Connectedness and the Social Assurance scales. J. Couns. Psychol. 1995, 42, 232-241. [CrossRef]

33. Williams, K.L.; Galliher, R.V. Predicting Depression and Self-Esteem from Social Connectedness, Support, and Competence. J. Soc. Clin. Psychol. 2006, 25, 855-874. [CrossRef]

34. Yeh, C.J.; Inose, M. International students' reported English fluency, social support satisfaction, and social connectedness as predictors of acculturative stress. Couns. Psychol. Q. 2003, 16, 15-28. [CrossRef]

35. Times Higher Education World University Rankings 2019: Methodology 2018. Available online: https:/ / www.timeshighereducation.com/world-university-rankings/methodology-world-universityrankings-2019\#survey-answer (accessed on 28 January 2019).

36. Vuong, Q.-H.; Bui, Q.-K.; La, V.-P.; Vuong, T.-T.; Nguyen, V.-H.T.; Ho, M.-T.; Nguyen, H.-K.T.; Ho, M.-T. Cultural additivity: Behavioural insights from the interaction of Confucianism, Buddhism and Taoism in folktales. Palgrave Commun. 2018, 4, 143. [CrossRef]

37. Pekerti, A.A.; Thomas, D.C. n-Culturals: Modeling the multicultural identity. Cross Cult. Strateg. Manag. 2016, 23, 101-127. [CrossRef]

38. Pekerti, A.A.; Vuong, Q.H.; Napier, N.K. Double edge experiences of expatriate acculturation: Navigating through personal multiculturalism. J. Glob. Mobil. 2017, 5, 225-250. [CrossRef]

39. APU. Awards and Rankings; APU: Oita, Japan, 2018; Available online: http://en.apu.ac.jp/home/about/ content177/ (accessed on 23 December 2018).

40. APU. APU Student Numbers as of May 2017; APU: Oita, Japan, 2017; Available online: http:/ / en.apu.ac.jp / home/news/article/?storyid=2865 (accessed on 23 December 2018).

41. APU. APU Outline; APU: Oita, Japan, 2018; Available online: http://en.apu.ac.jp/home/about/content55/ (accessed on 23 December 2018).

42. Kroenke, K.; Spitzer, R.L. The PHQ-9: A New Depression Diagnostic and Severity Measure. Psychiatr. Ann. 2002, 32, 509-515. [CrossRef]

43. Kroenke, K.; Spitzer, R.L.; Williams, J.B.W. The PHQ-9: Validity of a brief depression severity measure. J. Gen. Intern. Med. 2001, 16, 606-613. [CrossRef] [PubMed]

44. Eisenberg, D.; Golberstein, E.; Gollust, S.E. Help-Seeking and Access to Mental Health Care in a University Student Population. Med. Care 2007, 47, 594-601. [CrossRef] [PubMed]

45. Eisenberg, D.; Gollust, S.E.; Golberstein, E.; Hefner, J.L. Prevalence and correlates of depression, anxiety, and suicidality among university students. Am. J. Orthopsychiatr. 2007, 77, 534-542. [CrossRef] [PubMed]

46. Spitzer, R.L. Validation and Utility of a Self-report Version of PRIME-MDThe PHQ Primary Care Study. JAMA 1999, 282, 1737. [CrossRef] 
47. Han, X.; Han, X.; Luo, Q.; Jacobs, S.; Jean-Baptiste, M. Report of a Mental Health Survey Among Chinese International Students at Yale University. J. Am. Coll. Health 2013, 61, 1-8. [CrossRef]

48. Eisenberg, D.; Hunt, J.; Speer, N.; Zivin, K. Mental Health Service Utilization Among College Students in the United States. J. Nerv. Ment. Dis. 2011, 199, 301-308. [CrossRef]

49. Hendrickson, B.; Rosen, D.; Aune, R.K. An analysis of friendship networks, social connectedness, homesickness, and satisfaction levels of international students. Int. J. Intercult. Relat. 2011, 35, 281-295. [CrossRef]

50. Cao, C.; Meng, Q.; Shang, L. How can Chinese international students' host-national contact contribute to social connectedness, social support and reduced prejudice in the mainstream society? Testing a moderated mediation model. Int. J. Intercult. Relat. 2018, 63, 43-52. [CrossRef]

51. Lee, R.M.; Keough, K.A.; Sexton, J.D. Social Connectedness, Social Appraisal, and Perceived Stress in College Women and Men. J. Couns. Dev. 2002, 80, 355-361. [CrossRef]

52. Lee, R.M.; Robbins, S.B. Understanding Social Connectedness in College Women and Men. J. Couns. Dev. 2000, 78, 484-491. [CrossRef]

53. Lee, R.M.; Robbins, S.B. The relationship between social connectedness and anxiety, self-esteem, and social identity. J. Couns. Psychol. 1998, 45, 338-345. [CrossRef]

54. Sandhu, D.S.; Asrabadi, B.R. Development of an Acculturative Stress Scale for International Students: Preliminary Findings. Psychol. Rep. 1994, 75, 435-448. [CrossRef] [PubMed]

55. Yang, N.; Xu, Y.; Chen, X.; Yu, B.; Yan, H.; Li, S. Acculturative stress, poor mental health and condom-use intention among international students in China. Health Educ. J. 2018, 77, 142-155. [CrossRef]

56. Vuong, Q.-H.; Ho, T.-M.; Nguyen, H.-K.; Vuong, T.-T. Healthcare consumers' sensitivity to costs: A reflection on behavioural economics from an emerging market. Palgrave Commun. 2018, 4, 70. [CrossRef]

57. Hefner, J.; Eisenberg, D. Social support and mental health among college students. Am. J. Orthopsychiatr. 2009, 79, 491-499. [CrossRef]

58. Keyes, C.L.M.; Eisenberg, D.; Perry, G.S.; Dube, S.R.; Kroenke, K.; Dhingra, S.S. The Relationship of Level of Positive Mental Health with Current Mental Disorders in Predicting Suicidal Behavior and Academic Impairment in College Students. J. Am. Coll. Health 2012, 60, 126-133. [CrossRef]

59. Marconi, A.; Ranum, N.; Van Orman, S.; Hanson, B.; Donovan, V.; Borenitsch, E. Demographic differences in response rates for PHQ9 in a university student population. J. Am. Coll. Health 2018, 1-7. [CrossRef]

60. Benesty, J.; Chen, J.; Huang, Y.; Cohen, I. Pearson Correlation Coefficient. In Noise Reduction in Speech Processing; Springer: Berlin/Heidelberg, Germany, 2009; Volume 2, pp. 1-4. ISBN 978-3-642-00295-3.

61. Ogunsanya, M.E.; Bamgbade, B.A.; Thach, A.V.; Sudhapalli, P.; Rascati, K.L. Determinants of health-related quality of life in international graduate students. Curr. Pharm. Teach. Learn. 2018, 10, 413-422. [CrossRef] [PubMed]

62. Dogra, S.; MacIntosh, L.; O'Neill, C.; D'Silva, C.; Shearer, H.; Smith, K.; Côté, P. The association of physical activity with depression and stress among post-secondary school students: A systematic review. Ment. Health Phys. Act. 2018, 14, 146-156. [CrossRef]

63. Lex, H.; Ginsburg, Y.; Sitzmann, A.F.; Grayhack, C.; Maixner, D.F.; Mickey, B.J. Quality of life across domains among individuals with treatment-resistant depression. J. Affect. Disord. 2019, 243, 401-407. [CrossRef] [PubMed]

64. Md, T.L.; Mb, C.J.; Mm, Y.-F.P.; Mb, W.Z.; Mb, X.F. Correlation between premature ejaculation and psychological disorders in 270 Chinese outpatients. Psychiatry Res. 2019, 272, 69-72. [CrossRef] [PubMed]

65. Lee Rodgers, J.; Nicewander, W.A. Thirteen Ways to Look at the Correlation Coefficient. Am. Stat. 1988, 42, 59-66. [CrossRef]

66. Mui, A.C.; Kang, S.-Y. Acculturation Stress and Depression among Asian Immigrant Elders. Soc. Work 2006, 51, 243-255. [CrossRef]

67. Rousseeuw, P.J.; Hubert, M. Robust statistics for outlier detection: Robust statistics for outlier detection. WIREs Data Min. Knowl. Discov. 2011, 1, 73-79. [CrossRef]

68. Vuong, Q.H.; Napier, N.K.; Tran, T.D. A categorical data analysis on relationships between culture, creativity and business stage: The case of Vietnam. Int. J. Transit. Innov. Syst. 2013, 3, 4. [CrossRef]

69. Cohen, J.; Cohen, J. (Eds.) Applied Multiple Regression/Correlation Analysis for the Behavioral Sciences, 3rd ed.; L. Erlbaum Associates: Mahwah, NJ, USA, 2003; ISBN 978-0-8058-2223-6. 
70. Vuong, Q.H.; Napier, N.K. Acculturation and global mindsponge: An emerging market perspective. Int. J. Intercult. Relat. 2015, 49, 354-367. [CrossRef]

71. Takayama, Y.; Miura, E.; Miura, K.; Ono, S.; Ohkubo, C. Condition of depressive symptoms among Japanese dental students. Odontology 2011, 99, 179-187. [CrossRef]

72. Hyun, J.; Quinn, B.; Madon, T.; Lustig, S. Mental Health Need, Awareness, and Use of Counseling Services Among International Graduate Students. J. Am. Coll. Health 2007, 56, 109-118. [CrossRef] [PubMed]

73. Wilson, C.J.; Deane, F.P.; Ciarrochi, J.V.; Rickwood, D. Measuring help seeking intentions: Properties of the General Help Seeking Questionnaire. Can. J. Couns. 2005, 39, 15-28.

74. Beiter, R.; Nash, R.; McCrady, M.; Rhoades, D.; Linscomb, M.; Clarahan, M.; Sammut, S. The prevalence and correlates of depression, anxiety, and stress in a sample of college students. J. Affect. Disord. 2015, 173, 90-96. [CrossRef] [PubMed]

75. Steptoe, A.; ardle, J.; Tsuda, A.; Tanaka, Y. Depressive symptoms, socio-economic background, sense of control, and cultural factors in University students from 23 Countries. Int. J. Behav. Med. 2007, 14, 97-107. [CrossRef] [PubMed]

76. Misra, R.; Crist, M.; Burant, C.J. Relationships among Life Stress, Social Support, Academic Stressors, and Reactions to Stressors of International Students in the United States. Int. J. Stress Manag. 2003, 10, 137-157. [CrossRef]

77. Sümer, S.; Poyrazli, S.; Grahame, K. Predictors of Depression and Anxiety among International Students. J. Couns. Dev. 2008, 86, 429-437. [CrossRef]

78. Lester, D. Depression and suicide in college students and adolescents. Person. Individ. Differ. 1990, 7, 757-758. [CrossRef]

79. Mathews, G.; White, B. (Eds.) Japan's Changing Generations: Are Young People Creating a New Society? Japan Anthropology Workshop Series; Routledge Curzon: London, UK; New York, NY, USA, 2004; ISBN 978-0-415-32227-0.

80. Saunders, D.E.; Peterson, G.W.; Sampson, J.P.; Reardon, R.C. Relation of Depression and Dysfunctional Career Thinking to Career Indecision. J. Vocat. Behav. 2000, 56, 288-298. [CrossRef]

81. Rottinghaus, P.J.; Jenkins, N.; Jantzer, A.M. Relation of Depression and Affectivity to Career Decision Status and Self-Efficacy in College Students. J. Career Assess. 2009, 17, 271-285. [CrossRef]

82. Arnett, J.J. Emerging Adulthood: What Is It, and What Is It Good For? Child Dev. Perspect. 2007, 1, 68-73. [CrossRef]

83. Levine, M.D. Ready or Not, Here Life Comes; Simon \& Schuster: New York, NY, USA, 2006.

84. Hamilton, S.F.; Hamilton, M.A. School, Work, and Emerging Adulthood. In Emerging Adults in America: Coming of Age in the 21st Century; Arnett, J.J., Tanner, J.L., Eds.; American Psychological Association: Washington, DC, USA, 2006; pp. 257-277. ISBN 978-1-59147-329-9.

85. Côté, J.E. Arrested Adulthood: The Changing Nature of Maturity and Identity; New York University Press: New York, NY, USA, 2000; ISBN 978-0-8147-1598-7.

86. Smith, R.A.; Khawaja, N.G. A review of the acculturation experiences of international students. Int. J. Intercult. Relat. 2011, 35, 699-713. [CrossRef]

87. Vuong, Q.H.; Napier, N.K. Making creativity: The value of multiple filters in the innovation process. Int. J. Transit. Innov. Syst. 2014, 3, 294. [CrossRef]

88. Van Praag, H.M. Can stress cause depression? World J. Biol. Psychiatry 2005, 6, 5-22. [CrossRef] [PubMed]

89. Eraslan-Capan, B. Social Connectedness and Flourishing: The Mediating Role of Hopelessness. Univers. J. Educ. Res. 2016, 4, 933-940. [CrossRef]

90. Rice, K.G.; Leever, B.A.; Christopher, J.; Porter, J.D. Perfectionism, stress, and social (dis)connection: A short-term study of hopelessness, depression, and academic adjustment among honors students. J. Couns. Psychol. 2006, 53, 524-534. [CrossRef]

91. Furr, S.R.; Westefeld, J.S.; McConnell, G.N.; Jenkins, J.M. Suicide and depression among college students: A decade later. Prof. Psychol. Res. Pract. 2001, 32, 97-100. [CrossRef]

92. Wilbert, J.R.; Rupert, P.A. Dysfunctional attitudes, loneliness, and depression in college students. Cognit. Ther. Res. 1986, 10, 71-77. [CrossRef]

93. Rich, A.R.; Scovel, M. Causes of Depression in College Students: A Cross-Lagged Panel Correlational Analysis. Psychol. Rep. 1987, 60, 27-30. [CrossRef] 
94. Wei, M.; Russell, D.W.; Zakalik, R.A. Adult Attachment, Social Self-Efficacy, Self-Disclosure, Loneliness, and Subsequent Depression for Freshman College Students: A Longitudinal Study. J. Couns. Psychol. 2005, 52, 602-614. [CrossRef]

95. Rosembaum Asarnow, J.; Guthrite, D. Suicidal Behavior, Depression, and Hopelessness in Child Psychiatric Inpatients: A Replication and Extension. J. Clin. Child Psychol. 1989, 18, 129-136. [CrossRef]

96. Vuong, Q.H. Impacts of geographical locations and sociocultural traits on the Vietnamese entrepreneurship. SpringerPlus 2016, 5, 1189. [CrossRef] [PubMed]

97. Aryee, S.; Debrah, Y.A. A cross-cultural application of a career planning model. J. Organ. Behav. 1993, 14, 119-127. [CrossRef]

98. Krumboltz, J.D. Integrating Career and Personal Counseling. Career Dev. Q. 1993, 42, 143-148. [CrossRef]

99. Lyall, L.M.; Wyse, C.A.; Celis-Morales, C.A.; Lyall, D.M.; Cullen, B.; Mackay, D.; Ward, J.; Graham, N.; Strawbridge, R.J.; Gill, J.M.R.; et al. Seasonality of depressive symptoms in women but not in men: A cross-sectional study in the UK Biobank cohort. J. Affect. Disord. 2018, 229, 296-305. [CrossRef]

100. Oyane, N.M.F.; Bjelland, I.; Pallesen, S.; Holsten, F.; Bjorvatn, B. Seasonality is associated with anxiety and depression: The Hordaland health study. J. Affect. Disord. 2008, 105, 147-155. [CrossRef] [PubMed]

101. Vuong, Q.-H.; La, V.-P.; Vuong, T.-T.; Ho, M.-T.; Nguyen, H.-K.T.; Nguyen, V.-H.; Pham, H.-H.; Ho, M.-T. An open database of productivity in Vietnam's social sciences and humanities for public use. Sci. Data 2018, 5, 180188. [CrossRef] [PubMed]

(C) 2019 by the authors. Licensee MDPI, Basel, Switzerland. This article is an open access article distributed under the terms and conditions of the Creative Commons Attribution (CC BY) license (http://creativecommons.org/licenses/by/4.0/). 